\title{
Satan, a Projection of Milton in Paradise Lost
}

\author{
Zhang Li \\ Department of Foreign Languages \\ Yanan University \\ Yanan, 716000, Chin \\ 313508993@qq.com
}

\author{
$\mathrm{Xu}$ Wei \\ Department of Foreign Languages \\ Yanan University \\ Yanan, 716000, China \\ xuwei_1003@126.com
}

\begin{abstract}
This is to analyze how Milton projected his spirit and courage on Satan, the evil hero, in Paradise Lost. Satan is a word for "devil" because he is an adversary against God, a fallen angel for his arrogance and cockiness, and a great tempter of mankind. However, Satan is just a reflection of John Milton who ever joined the British revolutionary movement because of patriotism, got blind because of overwork, and was arrested because of the Restoration. Though lots of hardships tortured him, Milton had never given up his political and religious ambition. He created the hero, Satan, in Paradise Lost to show his distinguished spirit: bidding defiance to the old world, inspiring the companions with eloquence, feeling enthusiasm for the followers.
\end{abstract}

\section{Keywords_Paradise Lost, John Milton, Satan, projection}

\section{INTRODUCTION}

John Milton was a great poet politician and revolutionist in the 17th century. He stood next to Shakespeare among English poets; his writings and his influence were a very important part of the history of English literature, culture, and free thought. The intellectual person, who was unyielding to temptation and force and also to his bitter fate, wrote Paradise Lost as well as many other works to display his times and to struggle against the society with profound moral, political and religious thought. Milton, who rebelled against his king and his country, had an unconscious sympathy with Satan, who rebels against the government of the Almighty. He created Satan, and all Satan's characteristics reflected his fighting spirit. This paper will analyze the similar personalities between Satan and Milton: showing pride to the supreme power, loving freedom to give all liberty, bidding defiance to the old world, inspiring the companions with the ability of eloquence, feeling enthusiasm for the followers. This might prove that Satan is the projection of Milton's real life.

\section{ABOUT JOHN MiLTON AND HIS WORKS}

John Milton was born on December 9, 1608, in London where Shakespeare was living and writing. His father was a composer, and Milton grew up in the family of music, which influenced his future writings. The theme of his prose and verses was most about music. As a little boy, he had a strong thirst for knowledge. He always stayed up reading until midnight, which caused his weak eyes and even brought about his total blindness at the age of 44 . Milton ever studied at St. Paul School and Christ College, where he made friends and began to write verses. When he was at Cambridge University, he did not like the courses of feudal logic and he had conflict with the stubborn tutor and left for home. Form July, 1632 to the spring of 1638, he was in private reading at home. He pursued his voluntary course of humane study of literature, history and religion, and wrote Comus and Arcades, through which he was introduced to the artistic world. This laid the foundation of his liberal thinking. In April, 1637, Milton's mother died. In the spring of 1638, he began to fulfill his desire for a foreign travel in Europe. In 1639, because of growing political and religious friction in England, Milton got back to his country. He said,

The sad news of civil war in England called me back; for I considered it base that, while my fellow-countrymen were fighting at home for liberty. I should be traveling abroad for intellectual culture. [1]

Then his major preoccupation was on politics and society. He never stopped to debate and struggle against the revolution. He became a mature and somewhat embittered figure to publish his three great poems, Paradise Lost (1667), Paradise Regained (1671) and Samon Agonistes (1671). Paradise Regained is a tale of Reason and Passion discussing who shall win in man. Samon Agonistes_which is said as splendid as and much more human than Paradise Lost is a return to simplicity. These are his last three important works. On November 8, 1674, John Milton, the great English poet, passed away. However, his best-known work, Paradise Lost, remains immortal.

\section{FREE SPIRIT OF MILTON REFLECTED IN SATAN}

From the psychological and philosophical point of view we have taken in this work, Paradise Lost is the first of all the works out of Milton's ideas; but it is also a sort of transposition of his private and political experience, Milton created the defiant, eloquent and enthusiastic character in the poetry, and drew upon his own character to the hero, Satan, to express himself.

Satan is defiant to the supreme will and the terrible condition. Meanwhile Miiton also bid his defiance to his bitter fate. When he was young, he studied hard. From the age of twelve, he never went to bed before midnight, which was the main reason of his later weak eyes until blindness. At school, he began to write verses. In July of 1639, as the political struggles in his country began, Milton attacked in writing the corruption of the churches and the incomplete religious reformation and pointed out the autocracy and old ceremony of bishops. On 13th of February, 1649, two weeks later when Charles I was beheaded, his Eikonoklastes came out .He sharply pointed out that kings and 
officials were only entrusted to manage nations. Their real rights were in people's hands. People could punish and even kill them when they were not qualified. In 1651, he appeared in the European international arena as a political commentator. At that time, many writers and scholars were lured by Charles. II. Milton, one of whose eyes was blind and who was warned to be totally blind with hard work, put all his heart and soul into countering the reactionary scholars and wrote Defense for the English People. This brought about his total blindness and Claudius Salmasius, a respectable court scholar's death. After his blindness, he did not stop writing. His day began at 4:30 to medicate, compose and walk. He dictated to his devoted friends and daughter to complete his last three works. In 1660's Restoration, many leaders of parliament were beheaded. It was also a disaster for Milton. Most of his works were burnt and he himself was imprisoned. Many intellectuals changed these stances, but Milton stood firmly.

While he is bidding defiance to God, Satan is inspiring his mates with his eloquence to cheer them up and gain the ultimate success. He believes victory must come and they can return to heaven. When they are defeated to return, he calls to his mates,

O friends, why come not on these victors proud? Ere while they fierce were coming, and when we, To entertain them fail with open front

And breast (what could we more?), propounded terms

Of composition, straight they changed their minds,

Flew off, and into strange vagaries fell

As they would dance; yet for a dance they seemed

Somewhat extravagant and wild, perhaps

For joy of offered peace. [2]

Milton also inspired his English people to struggle against Restoration and establish a free Commonwealth. In 1651, he lost one of his eyes, but he continued to write pamphlets to save revolution crisis. This caused his complete blindness. Under the pressure of Restoration, Milton did not give up and insisted on his position firmly. He inspired people of England to struggle against the Restoration. His two Denfences gained the victory of mind in the world. His last political pamphlet, The Readie and Easie Way to Establish a Free Commonwealth, was published in March, 1660 and enlarged in April. "It was an act no less courageous than futile, since machinery was patently moving to bring back Charles II. Milton's pamphlet is a cry of incredulity and despair from the last champion of 'the good Old Cause”."[3] The glories of the Commonwealth, for which he himself had sacrificed 20 years and his eyes, were being swept away by feudal Restoration. Milton inspired people with his pamphlets and other works to establish a free Commonwealth. It was his great and last belief.

Satan is not only proud but also enthusiastic. He is enthusiastic over his revolt from God and about regaining his last realm. He struggles against God for freedom and equality. He also arouses the human desire for knowledge and power beyond the limit of human wisdom and stirs up Eve's ambition to be a goddess among the gods. He helps the innocent Man and Woman to gain knowledge and wisdom. He leads his fallen companions to fight and regain the heaven and he takes the alone adventure to the new world paradise.
Meanwhile the Adversary of God and man, Satan, With thoughts inflamed of highest design,

Puts on swift wings, and toward the gates of hell Explores his solitary flight; sometimes

He scours the right-hand coast, sometimes the left; Now shaves with level wing the deep, then soars Up to the fiery concave tow'ring high. [4]

This is Satan's enthusiasm over freedom and his mates. Milton was also enthusiastic over his country and his fellow people. In 1639, because of friction of politics and religion in England, he got back to his country and took part in the struggles actively until the revolution ended in 1660 . From 1641 to 1642, Milton wrote his first five pamphlets to attack traditionalism, formalism, worldliness and all things of bishops. (He was a good monarchist as well.) Two weeks after King Charles was executed, his first political tract The Tenure of Kings and Magistrates resigned the public mind to the event. Milton was too enthusiastic to keep his eyesight. He had been warned to be blind with continuance of writing, but he never gave up and became blind totally at last. In the Restoration, the government executed the Commonwealth leaders and hanged the body of Cromwell. Milton himself, as a noted defender of the king-killers, was in real danger, in the summer of 1660, a warrant was out for his arrest. He was protected by his friends. In August, The Act of Oblivion, granting pardon to most of the Commonwealth supporters, was passed. Milton was safe according to the act, but actually he could not escape the persecution. He was most likely to be in danger at any time, but he was never frightened. He was enthusiastic over the English people and over the revolution and over the fate of his country.

\section{CONCLUSION}

Milton is well-known for the great epic work, Paradise Lost, in which his "grand style" is used with supreme power; its characterization of Satan is one of the great achievements of world literature. Satan is an evil to God and to human beings. Human beings will never escape the sufferings of hardships. But from Milton's inner feelings, does Satan really mean “evil”? He had drawn upon his own personalities to his hero, Satan, in Paradise Lost: defiant to be frightened, inspiring to urge his followers on and enthusiastic to be suffered. All Satan's doctrine is Milton's spirit and the personality is Milton's projection. Satan in Paradise Lost reflects him in daily life. So the way Milton names his hero Satan implied the irony of the tyrannous government and the praise for the rebelling people.

\section{REFERENCES}

[1] Abrams, M. H., and Donaldson, E. Talbot, eds. The Norton Anthology of English Literature. 1974.

[2] Bush, Douglas, ed. Milton:Poetical Works, Oxford. 1983.

[3] Craig, Hardin. The Literature of the English Renaissance, Vol. II . 1962.

[4] Gwinn, Robert P. and others, eds. Encyclopedia Britannica. 1977. 